\title{
Assessment of Soil Fertility Status in major Betel Vine Growing Soils of Tumkur District of Southern Karnataka for Sustainable Production
}

\author{
D. Kalaivanan ${ }^{1 *}$, P. R. Ramesh ${ }^{2}$ and M. A. Suryanarayana ${ }^{1}$ \\ ${ }^{1}$ ICAR-Indian Institute of Horticultural Research, Bengaluru, India \\ ${ }^{2}$ Krishi Vignana Kendra (KVK), ICAR-IIHR, Hirehalli, Tumkur, Karnataka, India \\ *Corresponding author
}

\begin{abstract}
Keywords
Soil fertility, Soil depth, Betel vine, Nutrients,

Sustainable

Article Info

Accepted:

12 September 2019

Available Online:

10 October 2019 organic carbon status. The organic carbon content ranged from 0.57 to 1.05 per cent with a mean of 0.77 per cent. The distribution of organic carbon in soils showed a decreasing trend with depth. Based on the nutrient indexing in soils, the surface soil was medium in available $\mathrm{N}$ (276 to $349 \mathrm{~kg} \mathrm{ha}^{-1}$ ), available $\mathrm{P}$ (11.6 to $34.3 \mathrm{~kg} \mathrm{ha}^{-1}$ ) and available $\mathrm{K}$ (187 to $\left.243 \mathrm{~kg} \mathrm{ha}^{-1}\right)$. The exchangeable Ca content of the soil varied from 2.6 to $4.4 \mathrm{cmol}\left(\mathrm{p}^{+}\right) \mathrm{kg}^{-1}$ and was above $1.5 \mathrm{cmol}\left(\mathrm{p}^{+}\right) \mathrm{kg}^{-1}$ which is the critical value for ideal soils. Exchangeable $\mathrm{Mg}$ content of the soils varied from 0.78 to $1.97 \mathrm{cmol}(\mathrm{p}+) \mathrm{kg}^{-1}$ with an average value of $1.30 \mathrm{cmol}\left(\mathrm{p}^{+}\right) \mathrm{kg}^{-1}$ and found to be higher than the critical value of $1.0 \mathrm{cmol}(\mathrm{p}+) \mathrm{kg}^{-1}$ soil. The available sulphur in the soils varied from 9.4 to $15.1 \mathrm{mg} \mathrm{kg}^{-1}$. The DTPA extractable $\mathrm{Fe}, \mathrm{Mn}, \mathrm{Zn}$ and $\mathrm{Cu}$ contents in surface soils ranged from 12.1 to $22.3,3.6$ to $7.2,0.80$ to 1.7 and 0.3 to $0.9 \mathrm{mg} \mathrm{kg}^{-1}$, respectively and were sufficient in the surface soils. The contents of DTPA extractable $\mathrm{Fe}, \mathrm{Mn}, \mathrm{Zn}$ and $\mathrm{Cu}$ decreased with increase in soil depth. Soil analysis up to $60 \mathrm{~cm}$ soil depth revealed that betel vine plantations was high in organic carbon, medium in available $\mathrm{N}, \mathrm{P}, \mathrm{K}$ and $\mathrm{S}$, high in exchangeable $\mathrm{Ca}$ and $\mathrm{Mg}$, and sufficient in micronutrients. Contrary to the general perception, there has not been much depletion of soil fertility in betel vine growing soils of Tumkur district. Information generated on soil fertility status would be useful for optimum soil and nutrient management for ensuring sustainable betel vine production in the study area.
\end{abstract}

A B S T R A C T

A study was conducted to assess the soil fertility status of major betel vine growing soils of Tumkur district of Southern Karnataka for sustainable soil management and betel vine production. Thirty soil samples were collected at two different depths $(0-30$ and $31-60 \mathrm{~cm})$ from different betel vine plantations and analysed for $\mathrm{pH}$, electrical conductivity, organic carbon and available macro and micronutrients. Analytical results revealed that the soils of the study area were neutral to slightly alkaline in reaction, non-saline in nature and high in

\section{Introduction}

Betelvine (Piper betle L.) is a perennial dioecious climber and believed to have originated in Central and Eastern Malaysia. It is mainly cultivated in South East Asian countries viz., India, Bangladesh, Sri Lanka, Malaysia, Thailand, Philippines etc., for its leaves, which is mainly used as stimulant. It is a heritage crop of India, being mentioned in 
vedic literature and epics. Betel leaves are an integral part of all Hindu customs and religious ceremonies. Chewing pan is an ageold custom in Asia especially in India. In addition, it has many medicinal properties and used widely in Indian system of medicine to cure indigestion, stomach ache, diarrhoea, flatulence and to heal wounds, scales and burns, swellings due to sprains, bruises; respiratory disorders, sore throat, constipation, boils and gum sores (Patra et al., 2016). The volatile oil of betel vine leaves has antibacterial and anti-fungal properties. Betel leaves are rich in fibre and minerals. It is one of the important commercial crop grown mostly by small and marginal farmers in the states of Assam, West Bengal, Bihar, Andhra Pradesh, Karnataka, Tamil Nadu, Maharashtra, Madhya Pradesh, Kerala, Uttar Pradesh and Odisha with an estimated area of 53,539ha (Ray, 2008). Annual production is worth Rs. 9000 millions and estimated that about 20 million people earn their livelihood directly or indirectly partly or fully from production, processing, handling, transportation and marketing of betel leaves in India (Tallapragada and Seshachala, 2012; Mazumder et al., 2016). Betel leaves worth 30-40 million rupees are exported to countries like Bahrain, Canada, Great Britain, Nepal, Pakistan, Suadi Arabia, and many other European countries.

It is one of the most important commercial crops of Karnataka grown by small and marginal farmers. In Karnataka, it is grown in an area of 6988 ha with a production of $1,31,795$ lakh leaves with a productivity of 18.86 lakh leaves/ha. The important betelvine growing districts are Haveri, Davanagere, Tumkur, Bangalore Rural, Mysore, Dharwad, Shimoga, Chikmagalur, Belgaum and Bijapur. Haveri district is leading in Betelvine production followed by Davanagere, Tumkurand Ramanagara districts. Betelvine plants require partial shade and well-drained sandy loam or sandy clay soil with $\mathrm{pH}$ range of 5.6-8.2 for better production (Guha and Jain, 1997).Clay loam soil with rich of organic matter and adequate drainage also favour betel vine cultivation. It grows best under the shaded, tropical forest ecological conditions with a rainfall of about $2250-4750 \mathrm{~mm}$, relative humidity and temperature ranging from $40-80 \%$ and $15-40^{\circ} \mathrm{C}$, respectively. However, in the areas with lower rainfall $(1500-1700 \mathrm{~mm})$ the crop is cultivated with small and frequent irrigations, i.e. every day in summer and every 3-4 days in winter, whereas adequate drainage is required during the rainy season (Jana,1995; Mishra et al., 1997).

The sustainability of any land use system has become major concern in recent years. Achieving and maintaining appropriate levels of soil fertility, especially plant nutrient availability, is of paramount importance if agricultural land is to remain capable of sustaining crop production at an acceptable level. Therefore monitoring nutrient supplying capacity of soil will be key indicator of improving the sustainable agriculture production (Hartemink, 2006; Pathak, 2012). Soil quality assessment has been suggested as a tool for evaluating sustainability of soil and crop management practices (Hussian et al., 1999; Prabhavathi et al., 2013). Evaluation of soil fertility status of betel vine plantations is necessary because which forms the basis for the fertilizer recommendations for maximizing the crop yields and to maintain the adequate fertility in soils for longer period and also to minimize any adverse environmental impact due to excessive fertilizer application.

Therefore, the objective of this study was to assess/examine the soil fertility status of betelvine plantations for optimum soil management practices and for ensuring sustainable betel vine production in Tumkur districts of South Interior Karnataka. 


\section{Materials and Methods}

\section{Study area}

The study area is situated in a major betel vine growing belt, has red loamy and red sandy soils of the eastern rain shadow region of peninsular India. It is located at $848 \mathrm{~m}$ above mean sea level (MSL) with latitude of $13.33^{\circ} \mathrm{N}$ and longitude of $77.10^{\circ} \mathrm{E}$ (Fig. 2). The climate is semi-arid tropical with an average annual rainfall of $687 \mathrm{~mm}$, distributed mainly from June to November. The mean annual maximum and minimum temperature are $37.5^{\circ} \mathrm{C}$ and $12.8^{\circ} \mathrm{C}$, respectively. The area has ustic moisture regime and isohyperthermic temperature regime and covering both rainfed and irrigated system.

\section{Soil sampling and processing}

Soil samples collected at two different depths $(0-30$ and $31-60 \mathrm{~cm})$ from thirty (30) different betel vine plantations situated in Tumkur taluk of Southern Karnataka for assessing their fertility status. The soil samples collected from dense betelvine land use were bulked for each depth, thoroughly mixed and a composite sample taken for analysis. The soil samples were then air-dried, powdered and sieved using $2 \mathrm{~mm}$ sieve. Processed soil samples were then used for characterization of physico-chemical and chemical properties.

\section{Laboratory analysis}

Electrical conductivity, $\mathrm{pH}$ and organic carbon were determined by standard methods (Jackson 1973). Soil pH and electrical conductivity (EC)were measured in a 1:2.5 (w/v) soil/water mixture. Organic carbon content of the soils was determined using dichromate wet oxidation method of Walkley and Black (1934). Available nitrogen was estimated by alkaline permanganate method (Subbaiah and Asija, 1956). For available phosphorus, extraction was done using Olsen extracting reagent and determined by molybdophosphoric blue colour method (Jackson, 1973). Available potassium was extracted using neutral normal ammonium acetate and measured with flame photometer (Jackson, 1973). Sulphur was extracted using 0.15 per cent $\mathrm{CaCl}_{2}$ solution and was made to react with $\mathrm{BaCl}_{2}$ to form turbid solution of $\mathrm{BaSO}_{4}$.

The intensity of turbidity was measured using spectrophotometer at a wavelength of $420 \mathrm{~nm}$ (Jackson, 1973). Exchangeable calcium and magnesium were determined using versenate (EDTA) titration method. Available micronutrients such as iron, copper, manganese and zinc were extracted using standard DTPA extract at $\mathrm{pH} 7.3$ and the concentration was measured in an atomic absorption spectrophotometer (Lindsay and Norvell, 1978).

\section{Nutrient index calculation}

Based on the soil test values for different nutrients, soil samples are generally classified into three categories, low, medium and high (Table 1).

Using these fertility classes' nutrient indexes was calculated as per the following equation given by Parker (1951).

Nutrient index $=\left(\mathrm{N}_{\mathrm{L}} * 1+\mathrm{N}_{\mathrm{M}} * 2+\mathrm{N}_{\mathrm{H}} * 3\right) /$ $\mathrm{N}_{\mathrm{T}}$

Where, $N_{L}, N_{M}$ and $N_{H}$ are number of samples falling inlow, medium and high classes of nutrient status, respectively and $\mathrm{N}_{\mathrm{T}}$ is total number of samples analyzed for a given area. The nutrient index values less than 1.67 as the indicative of low nutrient status and between 1.67 to 2.33 as medium while higher than 2.33considered as high nutrient status (Ramamoorthy and Bajaj, 1969). 


\section{Statistical analysis}

The data for the soil physico-chemical and chemical properties were averaged over the number of sites sampled and the standard deviation as well as standard error computed. Coefficients of variation among the means were also calculated.

\section{Results and Discussion}

The summary of the analytical outcomes on soil $\mathrm{pH}$, electrical conductivity, organic carbon and macro and micronutrient status of the soils of betel vine plantations is presented in table 2 and 3.

\section{Soil pH}

Soil $\mathrm{pH}$ is important estimation for soils, determines the magnitude of the acidity and alkalinity and directly influences agriculture productivity. The $\mathrm{pH}$ value reflects the integrated effect of the acid base reactions taking place in the soil system. The surface soil $\mathrm{pH}$ of the study area varied from 6.94 to 7.72 with a mean of 7.47 and found to be very much ideal or safest for betel vine cultivation (Guha and Jain, 1997).

Slight increase in soil $\mathrm{pH}$ along the depth of the soil was observed and given in Table $2 \&$ 3 . The data on soil $\mathrm{pH}$ showed least variability $(1.8-2.4 \%)$ among the soil samples. Neutral to slightly alkaline $\mathrm{pH}$ of the soil might be attributed mainly to the prevalence of dry climate in the study area and also the crystalline schists and granitic gneisses parent materials (Srinivasan et al., 2013).

Soil $\mathrm{pH}$ was relatively higher in lower depths as compared to higher depths. This could be due to leaching of basic cations from surface layers to the lower layers coupled with higher content of clay in lower layers of soil (Kalaivanan and Sudhir, 2012).

\section{Electrical conductivity (EC)}

Electrical conductivity (EC) is a measurement that correlates with soil properties that effect productivity, including soil texture, cation exchange capacity (CEC), drainage conditions, organic matter level, salinity, and subsoil characteristics. The electrical conductivity (EC) of the surface soil varied from 0.18 to $0.32 \mathrm{dSm}^{-1}$ with a mean value of $0.27 \mathrm{dSm}^{-1}$. The EC of the soil slightly increased with depth. Electrical conductivity of the study area showed moderate variability with CV of $17 \%$ for surface soils and $19.1 \%$ for subsurface soils compared to soil $\mathrm{pH}$. Study area has EC of less than $1.0 \mathrm{dSm}^{-1}$ which indicates that the soils are free from salinity and found to be very much suitable for betel vine cultivation. Low EC in the study area could be related to the amount of rainfall of the area and texture of the soil (Kalaivanan and Sudhir, 2012).

\section{Organic carbon}

Organic matter is an important store house of plant essential nutrients. It supplies plant nutrient, improve the soil structure, water infiltration and retention, feeds soil microflora and fauna, and the retention and cycling of applied fertilizer. Soils are low in inorganic nutrients rely on the recycling of nutrients from soil organic matter to maintain fertility (Tiessen et al., 1994; Manlay et al., 2007). The organic carbon content ranged from 0.57 1.05 per cent with a mean of 0.77 per cent in surface soils $(0-30 \mathrm{~cm})$, indicating that the soils were high in organic carbon status (Table $2 \& 3$ ). The distribution of organic carbon in soils showed a decreasing trend with depth. Nutrient index data also indicated that the soil organic carbon was decreased from high (2.57) to medium(2.30) in status with increasing soils depth (Table 4). High organic carbon content in surface soils could be due to leaf litter falls from the standing crop and 
addition of organic manures (Srinivasan et al., 2013; Maria and Yost, 2006). Leaf litter fall from the live supports/standards i.e. Sesbania grandiflora (Agathi), Sesbania sesban, Erythrina variegate (Dadap), Moringa oleifera (Drumstick), Ceibapen tandra (Silk cotton tree) available in the plantations and from betel vine plants itself might have helped in enhancing the organic carbon status of the soils.

\section{Available Macronutrients}

Based on the nutrient indexing in soils, the study area surface soil was medium in available $\mathrm{N}$ (276 to $349 \mathrm{~kg} \mathrm{ha}^{-1}$ ), medium to high in available $\mathrm{P}$ (11.6 to $34.3 \mathrm{~kg} \mathrm{ha}^{-1}$ ) and medium in available $\mathrm{K}$ (187 to $243 \mathrm{~kg} \mathrm{ha}^{-1}$ ) (Table 2). Medium status of nitrogen, phosphorus and potassium in betel vine cultivated fields might be ascribed to regular uptake of nutrient by crops, which tended to deplete nutrient status in soils (Somasundaram, 2012). A consistent decrease in the concentration of available $\mathrm{N}, \mathrm{P}$ and $\mathrm{K}$ with the increase in soil depth was notedin Table $3 \& 4$. Available nitrogen contents of soils were in accordance with the carbon contents of soils in most cases. The relationship between available nitrogen and organic carbon content is well known (Ghosh et al., 2009). However the Available $\mathrm{N}$ content was found to be higher in surface soils and decreased with increased soil depth, which might possibly be due to the accumulation of plant residues, debris and rhizosphere (AbdelRahman et al., 2016). The decrease in available nitrogen content with increase in soil depth could be directly related to the lower organic matter content in lower depths.

Availability of phosphorus in soil is related mainly to the soil properties and the total phosphorus content. Highest available P was observed in the surface horizons and decreased regularly with depth (Fig. 1).
Higher $\mathrm{P}$ in the surface horizon might be due to the confinement of crop cultivation to this layer and supplementation of the depleted phosphorus through external sources i.e. fertilizers (Srinivasan et al., 2013). The reasons for higher soil available phosphorus in betel vine plantations could be attributed to the neutral soil reaction and release of phosphorus unavailable forms from organic materials due to higher activity of microorganisms in soils (Mallikarjuna et al., 2003).Low available phosphorus in subsurface soils was due to fixation of phosphorusby iron and $\mathrm{Al}$ oxides. The lower phosphorus content in sub-surface horizons could also be attributed to the fixation of released phosphorus by clay minerals and the presence of $\mathrm{Ca}$. The highest available $\mathrm{K}$ content was noticed in the surface horizons and showed decreasing trend with depth. This could be attributed to more intensive weathering, release of labile $\mathrm{K}$ from organic residues, low amounts of rainfall and application of $\mathrm{K}$ fertilizers (Srinivasan et al., 2013; AbdelRahman et al., 2016). The available sulphur in the soils varied from 9.4 to $15.1 \mathrm{mg}$ $\mathrm{kg}^{-1}$ and most of the soils were medium in ratings. Due to higher amount of organic matter in surface than in subsurface layers, the available sulphur was more in surface horizons than the sub-surface horizons.

\section{Exchangeable Calcium}

Exchangeable calcium plus magnesium usually accounts for more than sixty percent of exchangeable cations occurring in soils of $\mathrm{pH} 5.5$ or more. Soils usually contain less magnesium than calcium because $\mathrm{Mg}^{2+}$ ion is strongly adsorbed by clay and organic matter and further $\mathrm{Mg}^{2+}$ ions are more susceptible to leaching than $\mathrm{Ca}^{2+}$ ions.

The exchangeable $\mathrm{Ca}$ content of the soil varied from 2.6 to $4.4 \mathrm{cmol}\left(\mathrm{p}^{+}\right) \mathrm{kg}^{-1}$ soils with a mean value of $3.51 \mathrm{cmol}(\mathrm{p}+) \mathrm{kg}^{-1}$. The 
exchangeable $\mathrm{Ca}$ content of the betel vine plantations soil was above $1.5 \mathrm{cmol}(\mathrm{p}+) \mathrm{kg}^{-1}$ which indicates that $\mathrm{Ca}$ is sufficient in different depths of the soils. Exchangeable $\mathrm{Ca}$ content of the soil showed irregular trend with depth.

Table.1 Soil fertility ratings based on soil test values

\begin{tabular}{|c|c|c|c|}
\hline Soil nutrients & Low & Medium & High \\
\hline Organic C (\%) & $<0.5$ & $0.5-0.75$ & $>0.75$ \\
\hline Available $\mathbf{N}\left(\mathrm{kg} \mathrm{ha}^{-1}\right)$ & $<280$ & $280-560$ & $>560$ \\
\hline Olsen P $\left(\mathrm{kg} \mathrm{ha}^{-1}\right)$ & $<10$ & $10-25$ & $>25$ \\
\hline Ammonium acetate extractable $\mathrm{K}\left(\mathrm{kg} \mathrm{ha}^{-1}\right)$ & $<108$ & $108-280$ & $>280$ \\
\hline & \multicolumn{3}{|c|}{ Critical level in soil } \\
\hline Available S (mg kg $\left.{ }^{-1}\right)$ & \multicolumn{3}{|c|}{10} \\
\hline Exchangeable Ca $\left(\mathrm{c} \mathrm{mol}\left(\mathrm{p}^{+}\right) \mathrm{kg}^{-1}\right)$ & \multicolumn{3}{|c|}{1.5} \\
\hline Exchangeable Mg $\left(\mathrm{c} \mathrm{mol}\left(\mathrm{p}^{+}\right) \mathrm{kg}^{-1}\right)$ & \multicolumn{3}{|c|}{1.0} \\
\hline DTPA extractable Fe $\left(\mathrm{mg} \mathrm{kg}^{-1}\right)$ & \multicolumn{3}{|c|}{4.5} \\
\hline DTPA extractable Mn $\left(\mathrm{mg} \mathrm{kg}^{-1}\right)$ & \multicolumn{3}{|c|}{2.0} \\
\hline DTPA extractable $\mathrm{Zn}\left(\mathrm{mg} \mathrm{kg}^{-1}\right)$ & \multicolumn{3}{|c|}{0.6} \\
\hline DTPA extractable $\mathrm{Cu}\left(\mathrm{mg} \mathrm{kg}^{-1}\right)$ & \multicolumn{3}{|c|}{0.2} \\
\hline
\end{tabular}

(Source: Muhr et al., 1965; Lindsay and Norvell, 1978)

Fig.1 Available N, P and K status in surface and subsurface soils of betel vine plantation

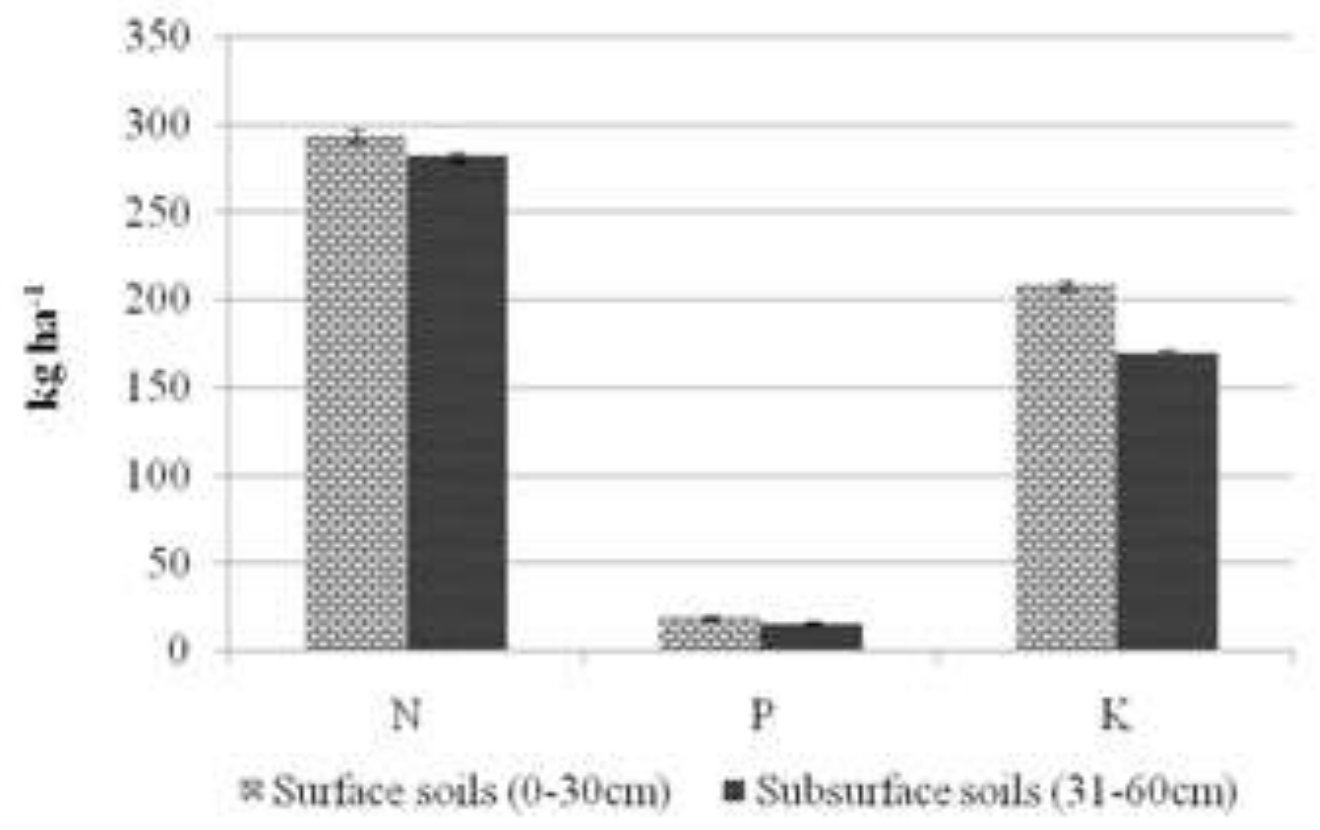


Table.2 Physico-chemical properties of surfaces soils $(0-30 \mathrm{~cm})$ of betel vine growing areas of Tumkur district

\begin{tabular}{|c|c|c|c|c|c|c|c|c|c|c|c|c|c|}
\hline \multirow[t]{3}{*}{$\begin{array}{c}\text { Sample } \\
\text { No }\end{array}$} & \multirow[t]{3}{*}{$\begin{array}{c}\text { pH } \\
(1: 2.5)\end{array}$} & \multirow[t]{3}{*}{$\begin{array}{c}\mathrm{EC} \\
\mathrm{dSm}^{-1}\end{array}$} & \multirow[t]{3}{*}{$\begin{array}{l}\text { OC } \\
(\%)\end{array}$} & \multicolumn{3}{|c|}{$\begin{array}{c}\text { Available Macro } \\
\text { Nutrients }\end{array}$} & \multicolumn{2}{|c|}{ Exchangeable } & \multirow[t]{2}{*}{$\begin{array}{c}\text { Available } \\
\mathbf{S}\end{array}$} & \multicolumn{4}{|c|}{ Available Micro Nutrients } \\
\hline & & & & $\mathbf{N}$ & $\mathbf{P}$ & $\mathbf{K}$ & $\mathbf{C a}$ & Mg & & $\mathbf{F e}$ & Mn & $\mathbf{Z n}$ & $\mathrm{Cu}$ \\
\hline & & & & \multicolumn{3}{|c|}{$\mathrm{kg} \mathrm{ha}^{-1}$} & \multicolumn{2}{|c|}{ c mol $\left(p^{+}\right) \mathbf{k g}^{-1}$} & $\mathrm{mg} \mathrm{kg}^{-1}$ & \multicolumn{4}{|c|}{$\mathrm{mg} \mathrm{kg}^{-1}$} \\
\hline 2 & 7.52 & 0.18 & 1.02 & 349 & 34.3 & 224 & 4.4 & 1.75 & 13.4 & 18.6 & 6.6 & 1.6 & 0.9 \\
\hline 3 & 7.55 & 0.27 & 0.78 & 310 & 11.6 & 197 & 4.1 & 1.67 & 13.8 & 18 & 6.3 & 1.5 & 0.6 \\
\hline 6 & 7.40 & 0.32 & 0.76 & 295 & 15.2 & 221 & 3.2 & 1.52 & 11.7 & 17.3 & 5.2 & 1.4 & 0.7 \\
\hline 7 & 7.62 & 0.23 & 0.81 & 310 & 16.7 & 212 & 4.1 & 1.97 & 13.2 & 14.6 & 4.6 & 1.5 & 0.5 \\
\hline 8 & 7.65 & 0.26 & 0.66 & 278 & 15.8 & 200 & 3.8 & 1.42 & 9.8 & 14 & 4.3 & 1.1 & 0.3 \\
\hline 9 & 7.54 & 0.34 & 0.78 & 288 & 17.8 & 208 & 3.4 & 1.03 & 10.2 & 13.4 & 3.6 & 1.2 & 0.4 \\
\hline 10 & 6.98 & 0.19 & 0.89 & 294 & 18.2 & 202 & 3.6 & 1.12 & 11.4 & 13 & 4.9 & 1.4 & 0.4 \\
\hline 14 & 7.35 & 0.25 & 0.78 & 281 & 15.3 & 204 & 3.5 & 1.02 & 11.7 & 14.4 & 3.6 & 1.2 & 0.4 \\
\hline 15 & 7.40 & 0.36 & 0.67 & 279 & 17.2 & 194 & 2.6 & 0.78 & 10.2 & 12.1 & 3.9 & 0.8 & 0.3 \\
\hline 16 & 7.36 & 0.28 & 0.72 & 287 & 18.5 & 203 & 3.2 & 1.02 & 12.5 & 16.3 & 4.2 & 1.2 & 0.4 \\
\hline 17 & 7.71 & 0.26 & 0.68 & 278 & 17.4 & 195 & 3.5 & 1.12 & 9.7 & 14.7 & 4.6 & 1 & 0.3 \\
\hline 18 & 6.94 & 0.2 & 0.74 & 284 & 18.6 & 201 & 3.1 & 1.24 & 10.4 & 17 & 4.8 & 1.3 & 0.5 \\
\hline 19 & 7.62 & 0.31 & 0.68 & 281 & 17.2 & 198 & 3.7 & 1.32 & 10.2 & 13.5 & 3.6 & 1.1 & 0.4 \\
\hline 20 & 7.44 & 0.28 & 0.92 & 328 & 25.6 & 224 & 4.3 & 1.54 & 15.1 & 16.2 & 4.9 & 1.6 & 0.8 \\
\hline 21 & 7.38 & 0.26 & 0.58 & 277 & 16.7 & 198 & 3 & 0.96 & 9.4 & 18.3 & 4.3 & 0.9 & 0.3 \\
\hline 22 & 7.69 & 0.24 & 0.75 & 285 & 17.3 & 212 & 3.1 & 1.24 & 11.5 & 17.5 & 3.6 & 1.2 & 0.4 \\
\hline 23 & 7.72 & 0.31 & 0.81 & 289 & 18.4 & 214 & 3.3 & 1.26 & 12.2 & 16.8 & 4.9 & 1.4 & 0.5 \\
\hline
\end{tabular}




\begin{tabular}{|c|c|c|c|c|c|c|c|c|c|c|c|c|c|}
\hline 24 & 7.64 & 0.32 & 0.64 & 276 & 17.1 & 187 & 3.1 & 1.01 & 10.3 & 17.2 & 4.2 & 1.1 & 0.3 \\
\hline 25 & 7.39 & 0.28 & 0.78 & 282 & 17.8 & 192 & 3.6 & 1.28 & 11.2 & 14.6 & 4.6 & 1.3 & 0.4 \\
\hline 26 & 7.51 & 0.26 & 0.74 & 291 & 19.2 & 210 & 3.2 & 1.31 & 12.5 & 13.2 & 4.3 & 1.2 & 0.6 \\
\hline 27 & 7.38 & 0.3 & 0.7 & 278 & 16.7 & 189 & 2.8 & 0.92 & 10.2 & 18.3 & 4.9 & 1 & 0.4 \\
\hline 28 & 7.65 & 0.36 & 0.78 & 288 & 17.3 & 204 & 3.2 & 1.22 & 12.1 & 14.6 & 4.3 & 1.2 & 0.4 \\
\hline 29 & 7.36 & 0.26 & 0.67 & 283 & 16.4 & 215 & 3.4 & 1.28 & 11.3 & 17 & 3.6 & 1.1 & 0.5 \\
\hline 30 & 7.42 & 0.28 & 0.81 & 310 & 18.9 & 234 & 3.7 & 1.34 & 13.8 & 13.4 & 4.9 & 1.4 & 0.7 \\
\hline Min & 6.94 & 0.18 & 0.57 & 276 & 11.6 & 187 & 2.6 & 0.78 & 9.4 & 12.1 & 3.6 & 0.8 & 0.3 \\
\hline Stdev & 0.18 & 0.05 & 0.12 & 18.41 & 4.15 & 14.23 & 0.46 & 0.29 & 1.49 & 2.25 & 0.90 & 0.23 & 0.17 \\
\hline Stderr & 0.03 & 0.01 & 0.02 & 3.36 & 0.76 & 2.60 & 0.08 & 0.05 & 0.27 & 0.41 & 0.16 & 0.04 & 0.03 \\
\hline CV\% & 2.4 & 17.0 & 15.3 & 6.3 & 22.5 & 6.8 & 13.2 & 22.2 & 12.8 & 14.1 & 19.2 & 18.1 & 34.5 \\
\hline
\end{tabular}

Table.3 Physico-chemical properties of subsurface soils $(31-60 \mathrm{~cm})$ of betel vine growing areas of Tumkur district

\begin{tabular}{|c|c|c|c|c|c|c|c|c|c|c|c|c|c|}
\hline \multirow{3}{*}{$\begin{array}{c}\text { Sample } \\
\text { No }\end{array}$} & \multirow{3}{*}{$\begin{array}{c}\mathrm{pH} \\
(1: 2.5 \\
)\end{array}$} & \multirow[t]{3}{*}{$\begin{array}{c}E C \\
\mathrm{dSm}^{-1}\end{array}$} & \multirow[t]{3}{*}{$\begin{array}{l}\text { OC } \\
(\%)\end{array}$} & \multicolumn{3}{|c|}{$\begin{array}{c}\text { Available Macro } \\
\text { Nutrients }\end{array}$} & \multicolumn{2}{|c|}{ Exchangeable } & \multirow[t]{2}{*}{$\begin{array}{c}\text { Available } \\
\text { S }\end{array}$} & \multicolumn{4}{|c|}{ Available Micro Nutrients } \\
\hline & & & & $\mathbf{N}$ & $\mathbf{P}$ & $\mathbf{K}$ & Ca & Mg & & $\mathbf{F e}$ & Mn & $\mathbf{Z n}$ & $\mathbf{C u}$ \\
\hline & & & & \multicolumn{3}{|c|}{$\mathrm{kg} \mathrm{ha}^{-1}$} & \multicolumn{2}{|c|}{ c mol $\left(p^{+}\right) \mathbf{k g}^{-1}$} & $\mathrm{mg} \mathrm{kg}^{-1}$ & \multicolumn{4}{|c|}{$\mathrm{mg} \mathrm{kg}^{-1}$} \\
\hline 1 & 7.34 & 0.21 & 0.89 & 293 & 9.8 & 152 & 3.2 & 1.07 & 11.6 & 19.2 & 5.4 & 0.9 & 0.3 \\
\hline 2 & 7.45 & 0.21 & 0.81 & 272 & 11.6 & 157 & 4.6 & 1.6 & 9.0 & 16.5 & 4.1 & 1.1 & 0.5 \\
\hline 3 & 7.51 & 0.29 & 0.69 & 298 & 10.3 & 155 & 3.4 & 1.3 & 12.2 & 16.2 & 3.8 & 1.1 & 0.3 \\
\hline 4 & 7.72 & 0.32 & 0.71 & 284 & 11.9 & 197 & 3.8 & 1.33 & 8.6 & 17 & 2.6 & 0.7 & 0.2 \\
\hline 5 & 7.53 & 0.17 & 0.78 & 262 & 9.5 & 177 & 3.6 & 1.36 & 11.2 & 15.1 & 3.0 & 0.5 & 0.1 \\
\hline 6 & 7.51 & 0.35 & 0.74 & 291 & 13.8 & 181 & 2.8 & 0.92 & 10.2 & 14.2 & 3.2 & 0.7 & 0.3 \\
\hline 7 & 7.42 & 0.26 & 0.76 & 302 & 15.2 & 172 & 3.5 & 1.07 & 11.4 & 12.8 & 4.0 & 0.9 & 0.4 \\
\hline 8 & 7.67 & 0.29 & 0.61 & 270 & 14.4 & 160 & 3.2 & 0.92 & 8.7 & 12.4 & 3.5 & 0.5 & 0.2 \\
\hline
\end{tabular}




\begin{tabular}{|c|c|c|c|c|c|c|c|c|c|c|c|c|c|}
\hline 9 & 7.45 & 0.32 & 0.74 & 278 & 16.2 & 166 & 3.7 & 1.13 & 9.2 & 13.1 & 2.9 & 0.6 & 0.2 \\
\hline 10 & 7.18 & 0.22 & 0.82 & 282 & 17.5 & 182 & 2.8 & 0.88 & 10.1 & 12.5 & 3.4 & 0.6 & 0.2 \\
\hline 11 & 7.44 & 0.26 & 0.87 & 312 & 20.3 & 212 & 4.0 & 1.24 & 10.8 & 16.2 & 3.6 & 0.7 & 0.4 \\
\hline 12 & 7.56 & 0.28 & 0.55 & 268 & 17.3 & 174 & 3.5 & 1.12 & 8.1 & 14.5 & 2.8 & 0.4 & 0.1 \\
\hline 13 & 7.68 & 0.33 & 0.62 & 278 & 14.5 & 172 & 3.2 & 1.11 & 9.6 & 15.2 & 3.4 & 0.5 & 0.2 \\
\hline 14 & 7.55 & 0.27 & 0.75 & 280 & 15.8 & 164 & 3.8 & 1.04 & 10.3 & 16.1 & 3.8 & 0.6 & 0.3 \\
\hline 15 & 7.44 & 0.32 & 0.64 & 277 & 17.4 & 154 & 2.8 & 0.65 & 9.4 & 14.2 & 4.1 & 0.5 & 0.2 \\
\hline 16 & 7.56 & 0.36 & 0.7 & 282 & 18.1 & 163 & 3.0 & 0.68 & 10.6 & 14.4 & 4.2 & 0.6 & 0.3 \\
\hline 17 & 7.61 & 0.29 & 0.62 & 271 & 16.3 & 175 & 3.2 & 0.82 & 9.8 & 13.5 & 3.5 & 0.5 & 0.2 \\
\hline 18 & 7.14 & 0.23 & 0.69 & 280 & 18.2 & 161 & 3.0 & 0.86 & 10.6 & 13.2 & 2.9 & 0.7 & 0.3 \\
\hline 19 & 7.65 & 0.35 & 0.64 & 275 & 16.5 & 168 & 3.1 & 1.01 & 10.3 & 16.2 & 4.1 & 0.7 & 0.2 \\
\hline 20 & 7.47 & 0.28 & 0.86 & 314 & 23.4 & 174 & 3.4 & 1.32 & 13.8 & 12.5 & 3.7 & 1.2 & 0.4 \\
\hline 21 & 7.43 & 0.25 & 0.52 & 272 & 16.5 & 178 & 3.2 & 0.98 & 9.2 & 13.5 & 2.8 & 0.5 & 0.2 \\
\hline 22 & 7.66 & 0.28 & 0.74 & 275 & 16.3 & 182 & 3.4 & 1.05 & 10.2 & 14.3 & 3.2 & 0.6 & 0.2 \\
\hline 23 & 7.7 & 0.34 & 0.78 & 284 & 16.8 & 164 & 2.8 & 0.72 & 11.3 & 15.2 & 4.3 & 0.7 & 0.3 \\
\hline 24 & 7.54 & 0.31 & 0.63 & 270 & 17.2 & 156 & 2.6 & 0.76 & 9.4 & 16.3 & 2.6 & 0.4 & 0.2 \\
\hline 25 & 7.59 & 0.34 & 0.67 & 272 & 17.3 & 163 & 3.2 & 0.89 & 10.1 & 12.5 & 3.4 & 0.5 & 0.2 \\
\hline 26 & 7.61 & 0.24 & 0.68 & 288 & 18.9 & 170 & 3.0 & 1.02 & 10.7 & 11.9 & 4.3 & 0.6 & 0.3 \\
\hline 27 & 7.48 & 0.37 & 0.65 & 276 & 16.2 & 168 & 2.6 & 0.71 & 9.4 & 13.4 & 2.9 & 0.5 & 0.2 \\
\hline 28 & 7.56 & 0.41 & 0.72 & 282 & 16.7 & 162 & 3.3 & 1.24 & 10.2 & 14.3 & 4.1 & 0.6 & 0.2 \\
\hline 29 & 7.38 & 0.24 & 0.64 & 263 & 16.5 & 155 & 3.0 & 0.87 & 9.5 & 13.6 & 3.6 & 0.3 & 0.1 \\
\hline 30 & 7.47 & 0.33 & 0.71 & 289 & 17.8 & 164 & 3.2 & 1.23 & 10.4 & 15.3 & 4.2 & 0.6 & 0.3 \\
\hline Mean & 7.51 & 0.29 & 0.71 & 281.3 & 15.9 & 169.3 & 3.3 & 1.0 & 10.2 & 14.5 & 3.6 & 0.6 & 0.3 \\
\hline Max & 7.72 & 0.41 & 0.89 & 314 & 23.4 & 212 & 4.6 & 1.6 & 13.8 & 19.2 & 5.4 & 1.2 & 0.5 \\
\hline Min & 7.14 & 0.17 & 0.52 & 262 & 9.5 & 152 & 2.6 & 0.65 & 8.1 & 11.9 & 2.6 & 0.3 & 0.1 \\
\hline Stdev & 0.14 & 0.06 & 0.09 & 12.77 & 3.02 & 13.04 & 0.43 & 0.23 & 1.16 & 1.69 & 0.64 & 0.21 & 0.09 \\
\hline Stderr & 0.02 & 0.01 & 0.02 & 2.33 & 0.55 & 2.38 & 0.08 & 0.04 & 0.21 & 0.31 & 0.12 & 0.04 & 0.02 \\
\hline $\operatorname{CV}(\%)$ & 1.8 & 19.1 & 12.7 & 4.5 & 19.0 & 7.7 & 13.3 & 22.4 & 11.4 & 11.6 & 17.8 & 32.8 & 37.5 \\
\hline
\end{tabular}


Fig.2 Location map of the study area

\section{LOCATION MAP OF TUMKUR}

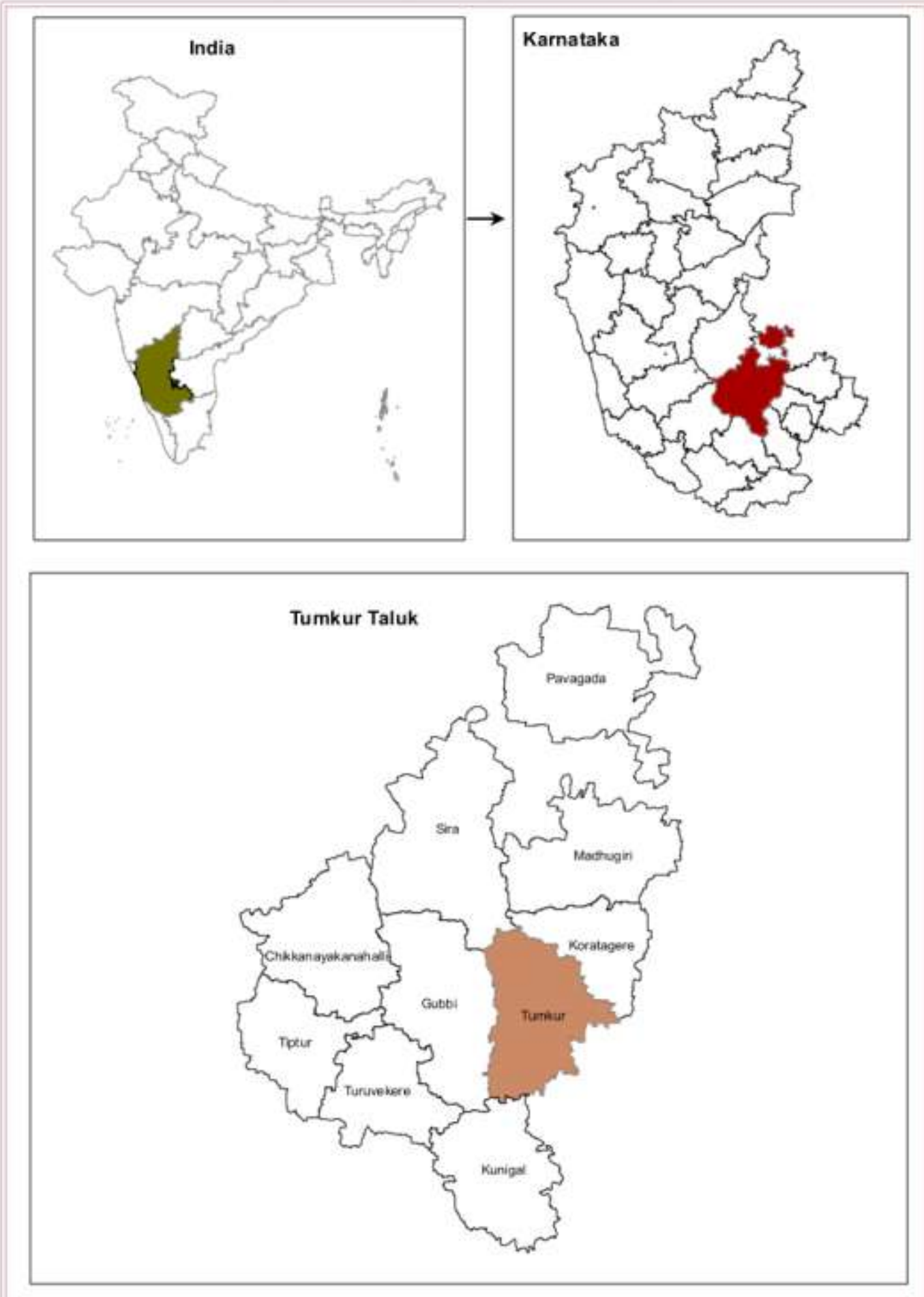


Table.4 Nutrient index of betel vine growing soils of Tumkur district.

\begin{tabular}{|c|c|c|c|}
\hline Soil properties & $\begin{array}{c}\text { Surface soils } \\
(\mathbf{0 - 3 0} \mathbf{c m})\end{array}$ & $\begin{array}{c}\text { Subsurface soils } \\
\mathbf{( 3 1 - 6 0 c m}\end{array}$ & $\begin{array}{c}\text { Entire soil depth } \\
\mathbf{( 0 - 6 0 c m})\end{array}$ \\
\hline Organic carbon & $2.57(\mathrm{H})$ & $2.30(\mathrm{M})$ & $2.44(\mathrm{H})$ \\
\hline Nitrogen & $1.90(\mathrm{M})$ & $1.50(\mathrm{~L})$ & $1.70(\mathrm{M})$ \\
\hline Phosphorus & $2.10(\mathrm{M})$ & $1.93(\mathrm{M})$ & $2.02(\mathrm{M})$ \\
\hline Potassium & $2.00(\mathrm{M})$ & $1.98(\mathrm{M})$ & $1.99(\mathrm{M})$ \\
\hline
\end{tabular}

L-Low in nutrient status, M-Medium in nutrient status and $\mathrm{H}$-High in nutrient status.

Fig.3 Micronutrient status in surface and subsurface soils of betel vine plantation

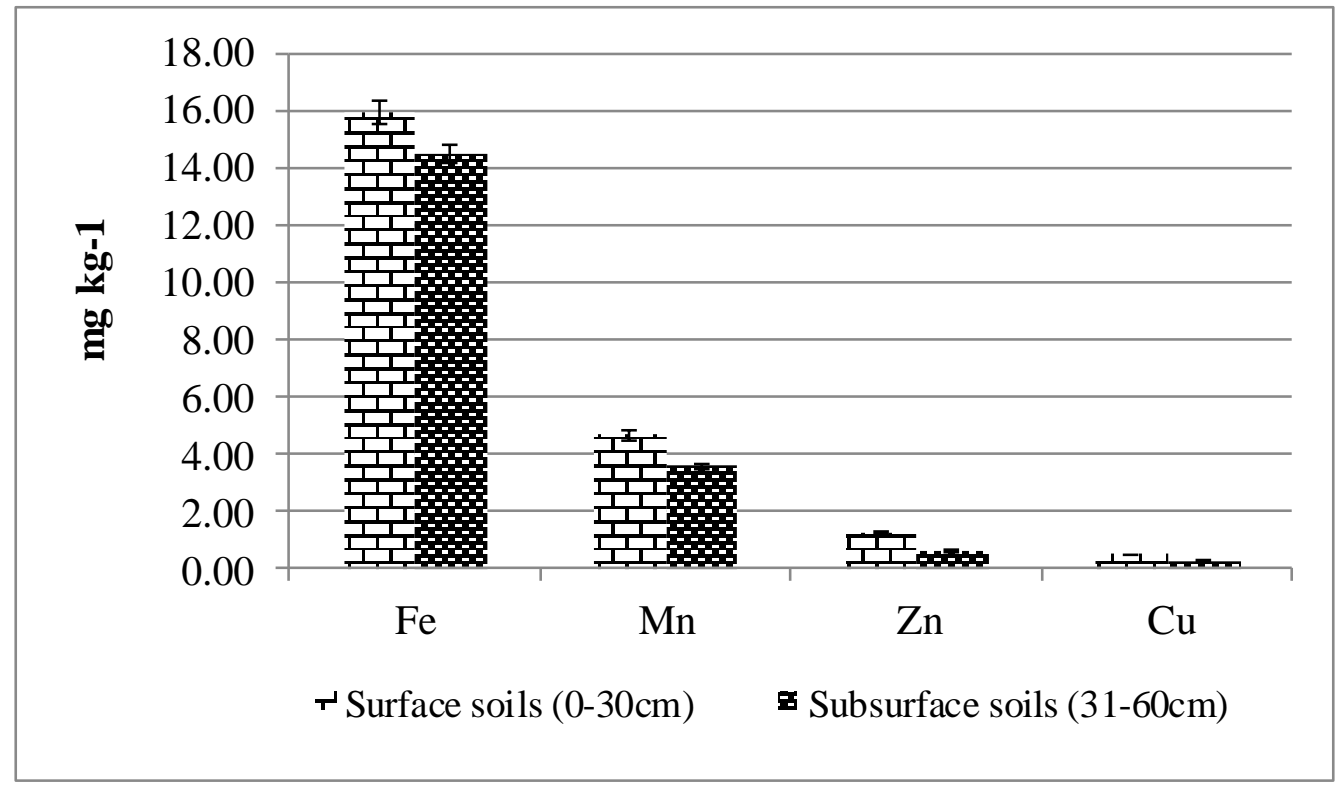

The results of the study indicated that the exchangeable calcium content was reasonably high in soils of all the sampling locations. The presence of higher amounts of calcium in the soil could not only be attributed to its high total content, but also due to the easy release of calcium in soluble forms from the solids to the solution phase. If soil conditions are ideal to retain $\mathrm{Ca}^{2+}$ ions on soil solid surfaces in exchangeable form, its content will hardly diminish even under continuous cropping situation (Sudhir and Jayaprakash 2004). The reason for relatively higher available calcium content in lower depths of soil could be attributed to the accumulation of carbonates and phosphates at lower depths.

\section{Exchangeable Magnesium}

The trend in the distribution of available magnesium in the soils was more or less similar to that of the distribution of available calcium in the soils. Exchangeable Mg content of the soils varied from 0.78 to $1.97 \mathrm{cmol}\left(\mathrm{p}^{+}\right)$ $\mathrm{kg}^{-1}$ with an average value of $1.30 \mathrm{cmol}\left(\mathrm{p}^{+}\right)$ $\mathrm{kg}^{-1}$. Exchangeable $\mathrm{Mg}$ content of most of betel vine plantations was higher than the critical value of $1.0 \mathrm{cmol}(\mathrm{p}+) \mathrm{kg}^{-1}$ soil. Depth wise distribution of $\mathrm{Mg}$ also followed a similar trend to that of exchangeable $\mathrm{Ca}$. 
Calcium and magnesium in their ionic forms behave similarly in soils with respect to their retention by soil colloids and leaching under acidic soil conditions. Hence, the reasons similar to the one quoted for exchangeable calcium could be given even for the distribution of available magnesium in soils.

The clay complex was dominated by exchangeable $\mathrm{Ca}$ in surface and subsurface horizons of most soils followed by $\mathrm{Mg}$ (Behera and Shukla, 2015). Exchangeable Ca and $\mathrm{Mg}$ showed irregular trend with depth of soils. Shanthakumari (2007) reported that the exchangeable calcium and magnesium content did not have a definite pattern with increase or decrease in the depth of soil.

\section{Available micronutrient}

The DTPA extractable Fe, $\mathrm{Mn}, \mathrm{Zn}$ and $\mathrm{Cu}$ contents in surface soils ranged from 12.1 to $22.3,3.6$ to $7.2,0.80$ to 1.7 and 0.3 to $0.9 \mathrm{mg}$ $\mathrm{kg}^{-1}$, respectively and were nearly sufficient in the surface soils (Table 2, 3 and Fig. 3). The critical limit for deficiency of the DTPA extractable $\mathrm{Fe}, \mathrm{Mn}, \mathrm{Zn}$ and $\mathrm{Cu}$ is 4.5, 2.0, 0.6 and $0.2 \mathrm{mg} \mathrm{kg}^{-1}$, respectively (Tandon, 1999).The high contents of DTPA extractable $\mathrm{Fe}, \mathrm{Mn}, \mathrm{Zn}$ and $\mathrm{Cu}$ in the surface soils could be due to the high organic matter content of the soil and addition of sufficient organic manures to the betel vine plantations (AbdelRahman et al., 2016). The contents of DTPA extractable $\mathrm{Fe}, \mathrm{Mn}, \mathrm{Zn}$ and $\mathrm{Cu}$ decreased with the increase in soil depth. The range of CV (14.1 to $34.5 \%$ for surface soils and $11.6-37.5 \%$ for subsurface soils) for the area suggested different degrees of heterogeneity among the DTPA extractable micronutrients studied.

The relatively high content of available zinc in surface horizons may be attributed to variable intensity of the pedogenic processes and complexing with organic matter which resulted in chelation of $\mathrm{Zn}$. The available $\mathrm{Cu}$ content was more in surface layers and decreased with depth, which might be due to association with organic carbon. The higher concentration of DTPA-Fe in subsurface soils might be due to the accumulation of iron brought down as a result of illuviation of clay from the upper horizons. However, the higher DTPA-Fe in surface horizons of all the pedons might be due to accumulation of organic carbon in the surface horizons. The organic carbon due to its affinity to influence the suitability and availability of iron by chelating action might have protected the iron from oxidation and precipitation, which consequently increased the availability of iron in the surface horizons (Prasad and Sakal 1991). The higher content of available $\mathrm{Mn}$ in surface soils was attributed to its chelation by organic compounds. These observations are in accordance with the findings of Verma et al., (2005). To optimize the productivity of fertilizer usage, it is imperative that the fertility status of the soil is known.Soil analysis up to $60 \mathrm{~cm}$ soil depth revealed that betel vine plantations of the study area was high in organic carbon, medium in available $\mathrm{N}, \mathrm{P}, \mathrm{K}$ and $\mathrm{S}$, high in exchangeable $\mathrm{Ca}$ and $\mathrm{Mg}$, and nearly sufficient in DTPA extractable $\mathrm{Fe}, \mathrm{Mn}, \mathrm{Zn}$ and $\mathrm{Cu}$. All the nutrients were higher in surface than subsurface soils. Contrary to the general perception, there has not been much depletion of soil fertility in betel vine growing soils of Tumkur district.

Results reported in this paper may be useful for optimum soil management practices for ensuring sustainable betel vine production in the region. Enhancement of soils in N, P, K and $\mathrm{S}$ elements could significantly increase crop yields.

Therefore, the application of organic manures viz., FYM, vermicompost and neem cake etc. along with recommended dose of fertilizers needs to be continued to improve soil fertility and crop productivity on sustainable basis. 


\section{Acknowledgement}

The authors are grateful to the Director, ICAR-Indian Institute of Horticultural Research for providing necessary facilities to carry out the work during the course of this investigation and the Indian Council of Agricultural Research (ICAR), New Delhi for providing required funds.

\section{References}

Abdelrahman MAE, Natarajan A, Srinivasamurthy $\mathrm{CA}$ and Hegde $\mathrm{R}$ (2016). Estimating soil fertility status in physically degraded land using GIS and remote sensing techniques in Chamarajanagar district, Karnataka, India. Egyptian Journal of Remote Sensing and Space Science 19(1): 95108.

Behera SKand Shukla AK(2015).Spatial distribution of surface soil acidity, electrical conductivity, soil organic carbon content and exchangeable potassium, calcium and magnesium in some cropped acid soils of India. Land Degradation and Development, 26: 7179.

Ghosh K, Bharadwaj KKR and Mohan Singh (2009). Soilorganic matter. In: Fundamentals of Soil Science, Indian Society of Soil Science, Prentice-Holl of India, Pvt. Ltd. New Delhi, pp567576.

Guha P and Jain RK (1997). Status report on production, processing and marketing of betel leaf (Piper betle L.), Agricultural and Food Engineering Department, IIT, Kharagpur, India.

Guha P (2006). Betel Leaf: The neglected green gold of India. Journal of Human Ecology, $19 \quad$ (2): $\quad 87-93$. doi:10.1080/09709274.2006.11905861
Hartemink AE (2006). Assessing Soil Fertility Decline in the Tropics Using Soil Chemical Data. Advances in Agronomy, $\quad$ 89: 179-225. doi:10.1016/S0065-2113(05)89004-2.

Jackson ML (1973). Soil chemical analysis, Prentice-Hall of India Pvt. Ltd. New Delhi, pp 40.

Jana BL (1996). Improved technology for betel leaf cultivation. A paper presented in the "Seminar-cumworkshop on betel leaf marketing" held during 5-6June 1996at State cashew nut farm, Directorate of Agricultural Marketing, Digha, Midnapur, West Bengal, India.

Kalaivanan D and Sudhir K(2012). Phosphorus fractions of selected banana growing soils of India and their relationships with soil characteristics. Mysore J. Agric, Sci., 46 (1): 73-79.

Katyal JC(2003).Soil fertility management-A key to prevents esertification. J. Indian Soc. Soil Sci., 51: 378-387

Lindsay WL and Norvell WA (1978). Development of a DTPA soil test for zinc, iron, manganese and copper. Soil Sci. Soc. Am. J., 42: 474-481.

MallikarjunaG, Sudhir K and Srinivasamurthy CA (2003). Phosphorus fixation capacity and its relationship with the soil characteristics in laterite soils of Karnataka. J. Indian Soc. Soil Sci., 51: 23-26.

Manlay RJ, Feller C and Swift MJ (2007). Historical evolution of soil organic matter concepts and their relationships with the fertility and sustainability. Agriculture, Ecosystems and Environment, 119 (3): 217-233. doi:10.1016/j.agee.2006.07.011.

Maria RM and Yost R(2006). A survey of soil fertility status of four agroecological zones of Mozambique. Soil Science, 171: 902-914. doi:10.1097/01.ss.0000228058. 38581. 
Mazumder S, Roychowdhury A and Banerjee $S$ (2016). An overview of betel leaf (Piper betle L.) - A review. Annals of Food Science and Technology 17: 367376.

Mishra D, Mishra SK, Acharya A and Das JN (1997). Annual Report of All India Coordinated Research Project on Betelvine. Department of Plant Pathology, College of Agriculture, Orissa University of Agriculture and Technology, Bhubaneswar, India.

Muhr GR, Datta NP, Shankar, Subramoney H, Liley VK and Donahue RL(1965).Soil testing in India.US Agency for International Development (USAID), New Delhi, pp 120.

Prasad R and Sakal R (1991).Availability of $\mathrm{Fe}$ in calcareous soils in relation to soil properties. Journal of the Indian Society of Soil Science, 39: 658-661.

Prabhavathi M, Patil, SL and Raizada A (2013). Assessment of soil fertility status for sustainable crop production in a watershed of Semi-Arid Tropics in Southern India. Indian Journal of Soil Conservation, 41(2): 151-157.

Parker FW, Nelson WL, Winter Eric and Miller LE (1951). The broad interpretation of soil test informations. Agron. J. 43:105-112.

Pathak H (2012). Trend of fertility status of Indian soils. Current Advances in Agricultural Sciences, 2(1): 10-12.

Patra G, Tanay BP, Das G, Kumar MP, Dey G, Biswajit SP, Patra G, Patra B, Tanay CP, Das M and Kumar Dey S. (2016). A review on Piper beetle L. Journal of Medicinal Plants Studies, 4: 185-192.

Ramamoorthy B and Bajaj JC (1969). Available N, P and K status of Indian soils. Fert. News, 14(8): 24-26

Ray DP (2008). Keynote Address, National Seminar on Piperaceae, 21-22 November 2008, IISR Calicut, India, pp26.

Shanthakumari S(2007). Distribution of secondary and micronutrients in an alfisol subjected to long-term fertilizer schedule and continuous cropping. M.Sc. (Agri.) Thesis, University of Agricultural Sciences, Bangalore.

Srinivasan R, Natarajan A, Anil Kumar KSand Kalaivanan D (2013). Distribution of available macro and micronutrients in cashew growing soils of Dakshina Kannada District of Coastal Karnataka. Madras Agric. J., 100 (1-3): 113-117.

Srinivasamurthy CA, Chidanandappa HM and Nagaraja MS(1999).Laboratory manual for methods of soil analysis. Department of Soil Science and Agricultural Chemistry, College of agriculture, UAS, GKVK, Bangalore65.

Stevenson FS(1982).Organic matter and nutrient availability. In: Non-symbiotic nitrogen fixation and organic matter in the tropics, Trans. $12^{\text {th }}$ Int. Cong. Soil Sci., New Delhi, India, pp 137-151.

Subbaiah BV and Asija GL (1956).A rapid procedure for estimation of available nitrogen in soils. Current Science,25: 259-260.

Sudhir Kand Jayaprakash SM (2004). Long term experiment to study the changes in soil quality, crop productivity and sustainability. Progress report presented in the work shop at Punjab Agricultural University, Ludhiana, pp17-22.

Suryanarayana MA, Vasantha Kumar T, HimaBindu $\mathrm{K}$ and Lokesha $\mathrm{AN}$ (2014). Status of betelvine cultivation in Karnataka. National meets on Betelvine - Farmers, Traders and Researchers Interface held at IIHR Bangalore, India.

Tiessen H, Cuevas $\mathrm{E}$ and Chacon $\mathrm{P}$ (1994). The role of soil organic matter in sustaining soil fertility. Nature, 371: 
783-785. doi:10.1038/371783a0.

Tallapragada P and Seshachala U (2012). Phosphate-solubilizing microbes and their occurrence in the rhizospheres of piper betel in Karnataka, India. Turkish Journal of Biology, 36: 25-35. doi:10.3906/biy-1012-160

Verma VK, Setia RK, Sharma PK, Charanjit Singh and Ashok Kumar (2005). Micronutrient distribution in soils developed on different physiographic units of Fatehgarh Sahib District of Punjab. Agropedology, 15: 70-75. examination of the Degtijareff method for determining soil organic matter and a proposed modification of the chromic and titration method. Soil Science, 37: 29-38.

Warren A and Agnew C(1988).An Assessment of desertification and land degradation in arid and semi arid areas. International Institute of Environmental Development, Drylands Farming. Ecology and Conservation Unit, University College, London, UK.

Walkley A and Black IA(1934). An

\section{How to cite this article:}

Kalaivanan, D., P. R. Ramesh and Suryanarayana, M. A. 2019. Assessment of Soil Fertility Status in major Betel Vine Growing Soils of Tumkur District of Southern Karnataka for Sustainable Production. Int.J.Curr.Microbiol.App.Sci. 8(10): 1751-1765. doi: https://doi.org/10.20546/ijcmas.2019.810.204 